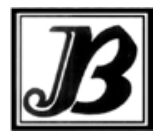

J. Bio-Sci. 27: 59-67, 2019

ISSN 1023-8654 http://www.banglajol.info/index.php/JBS/index DOI: https://doi.org/10.3329/jbs.v27i0.44671

\title{
FISH BIODIVERSITY AND LIVELIHOOD STATUS OF FISHERMEN LIVING AROUND THE TITAS RIVER OF BANGLADESH
}

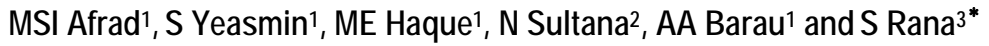 \\ ${ }^{1}$ Department of Agricultural Extension and Rural Development, Bangabandhu Sheikh Mujibur Rahman \\ Agricultural University, Gazipur, Bangladesh \\ 2Department of Fisheries Biology and Aquatic Environment, Bangabandhu Sheikh Mujibur Rahman \\ Agricultural University, Gazipur, Bangladesh \\ ${ }^{3}$ Department of Agricultural Economics and Social Sciences, Chittagong Veterinary and Animal Sciences \\ University, Chittagong, Bangladesh
}

\begin{abstract}
Fisheries biodiversity is important especially for the rural poor who often rely on fishing to earn their livelihoods. This study was carried out to examine the fish species diversity and livelihood status of fishermen around the Titas River falls under the villages of Radhanagar and Uzanchar at Bancharampur upazila of Brahmanbaria district. Data were collected from randomly selected 80 fishermen and analyzed using descriptive statistical tools, viz. frequency and percentage. A total of 55 fisheries species under 10 orders and 20 families were recorded from the Titas River. Cypriniformes was the most dominant order comprising 19 species followed by Siluriformes (12 species), Perciformes (8 species), Synbranchiformes (4 species), Channidiformes (3 species), Beloniformes (1 species), Osteoglossiformes (2 species), Clupeiformes (2 species) and Tetraodontiformes (2 species). Results also revealed that $60.0 \%$ of fishermen were belonged to the age group $31-50$ years and $75.0 \%$ of them had no individual water body of their own. All of the fishermen were male, of whom $83.7 \%$ were married living in kutcha house (55.0\%) and 52.5\% of their families were nuclear type consisting of husband wife and their children. The illiteracy rate among fishermen was $26.0 \%$, while $41.3 \%$ of them could sign only. Many fishermen (68.8\%) were able to sell their catch at local market and $60.0 \%$ had an annual income ranging BDT 71,000-100,000 (= USD 844.887-1189.92). Overall, fish biodiversity in the Titas River is declining as compared to abundance observed from previous findings. Moreover, the fishermen of that place are leading a poor life having lower income than that of the government minimum wage, a basic pay of BDT 8,250 per month.
\end{abstract}

Key words: Biodiversity, Fish, Fishermen, Livelihood, Titas River

\section{Introduction}

Bangladesh is a riverine country with about 700 rivers and tributaries, which constitute a waterway of total length about 24,140 km. The principal rivers include the Padma, the Meghna, the Jamuna, the Brahmaputra, the Dhaleswari and the Karnaphuli. Besides these, the Buriganga, the Sitallakya, the Gomoti, the Teesta, the Atrai, the Korotoa, the Mohananda, the Madhumati, the Titas and many others are rich in diverse aquatic species. There are 4,708,193 ha of inland water bodies in the form of ponds, rivers, beels (wetlands), haors, baors (oxbow lakes) etc., from where $3,085,048$ metric tons of fish (83.72\% of total national fish production) were harvested in 2014-15 (DoF 2015). These water bodies not only influence the life style of many people

*Author for correspondence: afrad69@gmail.com 
but also create diverse livelihood opportunities for rural people, many of whom live below the poverty line (Khanum 2013). Though, the number of people living below the poverty line has been decreasing over time (Khandaker et al. 2000, Karim 2008), reduced from 82\% in 1972 to 12.9\% in 2016 (World Bank 2018), most of the fishermen still live from hand-to-mouth (Rahman et al. 2013). Fishermen are one of the most vulnerable communities, and they are poor by any standard and their economic condition has deteriorated over the years (Khanum 2013). Being an isolated community, fishermen are deprived of many amenities of life (Khan et al. 2013).

Bangladesh ranks $5^{\text {th }}$ aquaculture producing country in the world according to the (2016) FAO statistics. Last 10 years average growth rate of fisheries was 5.4 percent where aquaculture shows the growth performance of 8.2 percent (FAO 2015). Bangladesh is blessed with a variety of fish species both freshwater and marine water. There are 260 freshwater fish species, 24 freshwater prawn species, 475 marine fish species and 36 shrimp species in the country. Besides, about 12 exotic species have been introduced into the country for their aquaculture potential. Around 1.316 million people are engaged in fishing, of them $60.8 \%$ are inland fishermen and the rests 39.2 percent are marine fishermen (DoF 2013). The biodiversity of this fish are categorized under different levels of threat such as, vulnerable (VU), endangered (EN) and critically endangered (CR) and so on. The International Union for Conservation of Nature (IUCN), Bangladesh (2015) assessed 253 freshwater fish species and revealed 64 as threatened species in Bangladesh, of which 9 were critically endangered, 30 were endangered, 25 were vulnerable, near threatened 27, least concern 122 and 40 data deficient freshwater species. So, biodiversity of different threatened fish species is very important to determine their diversity which helps in taking adequate measures to prevent extinction.

In Bangladesh, these threatened fish species have high market value as such people of those regions are highly involved in catching them. By and large, it is essential to identify these threatened fish species so then measures can be taken to control their extinction (Chakma 2015). In addition, the livelihood of these fishermen would also be of significant importance for intervention and policy formulation. Therefore the present study aimed at: 1) assess the status of fish species biodiversity in the Titas River; 2) describe the livelihood status (through socioeconomic profiling) of the fishermen living around the Titas River; and 3) document various problems faced by the fishermen and suggest probable solutions.

\section{Methodology}

The study area located around the Titas River covering two villages under Bancharampur upazila. The selected two villages were Radhanagar and Uzanchar. The villages were selected due to abundance of fish resources. About 200 fishing family live in these two villages. Among them a total of 80 fishermen, who were directly involved in fishing and earn for their family, were randomly selected to collect data. Fish biodiversity was measured based on change assessment (CBD 2003) following the methodology of Coll (2014). An interview schedule was developed and used for the collection of quantitative data. Similarly, Focus Group Discussion (FGD) was employed to generate qualitative information to validate results. Collected data were coded, compiled, tabulated and analyzed in accordance with the objectives of the study. All the collected quantitative data were analyzed by using SPSS/PC+ computer program (Statistical Package for Social Sciences). 


\section{Results and Discussion}

Results and their logical discussions have been presented in this section according to the objective of the study:

\section{Status of fish biodiversity}

The present status of fish species diversity in the Titas River is recorded based on the presence of different fish species in a taxonomic context. Thus, 55 fish species belonging to 10 orders were identified according to the fishermen' response (Table 1). Cypriniformes was the most dominant fish order in view of species variety. Different types of fish species were also found under the order of Siluriformes, Perciformes, Synbranchiformes, Channidiformes, Beloniformes, Osteoglossiformes, Decapoda, Clupeiformes and Tetraodontiformes in the Titas River. The order Cypriniformes was represented by 19 species belonging to 12 genera under 2 families; order Siluriformes includes 12 species belonging to 10 genera under 6 families; order Perciformes was represented by 8 species under 7 genera of 6 families; order Channiformes was represented by 3 species under 2 genera of single family Channidae; order Clupeiformes had 2 species belonging to 2 genera of single family; order Beloniformes was represented by 1 species under single genus of single family Belonidae; order Synbranchiformes was represented by 4 species under 3 genera of 3 families. Two species of fish were recorded from each order of Osteoglossiformes, Decapoda and Tetraodontiformes under single genus of single family.

Table 1. Distribution of the fisheries species according to their order

\begin{tabular}{clcc}
\hline & & \multicolumn{2}{c}{ Fisheries species } \\
\cline { 3 - 4 } Sl. No. & Order & No. & Percent (\%) \\
\hline 1. & Cypriniformes & 19 & 34.6 \\
2. & Siluriformes & 12 & 21.8 \\
3. & Perciformes & 8 & 14.6 \\
4. & Synbranchiformes & 4 & 7.3 \\
5. & Channiformes & 3 & 5.5 \\
6. & Clupeiformes & 2 & 3.6 \\
7. & Osteoglossiformes & 2 & 3.6 \\
8. & Decapoda & 2 & 3.6 \\
9. & Tetraodontiformes & 2 & 3.6 \\
10. & Beloniformes & 1 & 1.8 \\
\hline & Total & 55 & 100.0 \\
\hline
\end{tabular}

It has been observed that the total number of fish species has decreased, but species abundance of order Perciformes and Siluriformes have increased. Because Ahmed (2008) reported 57 fish species from the catches including two exotic species, Hypophthelmichthyes molitrix and Puntius gonionotus. Among the catches, there were high number (>20.0\% of total catch) of Cypriniformes (mostly carps) followed by Siluriformes (15.6\%), Perciformes (13.0\%), eels (5.4\%), and other small and medium sized fishes (46.0\%). 
The present findings and its comparison with previous records buttress the necessity of fisheries conservation measures in the Titas River.

\section{Socioe-conomic profile of the respondent fishermen}

The age of the respondents ranged 15-50 years of age. Results shown in Table 2 indicate that majority (60.0\%) of the fishermen belonged to middle age category (31-50), followed by $15-30$ years (23.7\%) and 50 years above (16.3\%). The old people (50 above years) were less involved in fishing as fishing is a hard work. On the other hand, middle age had much involvement in fishing because the age group is considered as the most active and they take more responsibilities to support their family. The young (15-30) has less interest in fishing perhaps due to intra and country migration in search of alternative to fishing. Rahman (2008) found that the age group of 30-40 years had the highest (67.5\%) and less than 30 years had the lowest (17.5\%) involvement in fishing in the Jamuna river of Bangladesh. Majority of the respondents were married (83.7\%) and few were unmarried (16.3\%). Marital status is an important social factor that sometimes play a role to change the livelihood status of respondents. Young and unmarried might not want to involve in fishing as it is a hard work. But, married people have many responsibilities. They, therefore, have to involve as it is readily available livelihood in order to support their family. A study by Zaman et al. (2006) involving 90 fish farmers of 52 villages under 6 unions in Mohanpur upazila indicated similar result where 87.8 percent were married and 12.2 percent were unmarried.

In rural Bangladesh, families are classified into two types: (1) nuclear family: married couples with children consisting of the members of two generations (parents and children), and (2) joint family: group of people related by blood and/or by law, which means members of three or more generations. The results show that more than half $(52.5 \%)$ of the respondents' families were nuclear while 47.5 percent belonged to joint family category. Rahman et al. (2012) in their study revealed that 41.7 percent belonged to nuclear family and 58.3 percent were joint family in the fishing communities of Nijhumdwip under Hatia upazila of Noakhali district in Bangladesh.

The observed family size of the respondents ranged 2-6 persons. Results indicate that majority $(60.0 \%)$ of the families were medium category (4-5 persons), 28.7 percent were large category ( 6 and above) and the remaining 11.3 percent were small category (2-4 persons). Thus, large proportion (88.7\%) of the respondents fall under medium and large family categories (4-6 above person). This is in line with the findings of Kosturi (2012) who found that family consisting of 4-6 members was majority (64.0\%) of the sampled respondents of the Chalan beel under Tarash upazila of Sirajganj district in Bangladesh.

There is a strong relationship between social status and education. In most cases the higher the education the better the livelihood opportunities. The observed educational status of the respondents ranged 0-10 years (illiterate to SSC level). In the study area, it was found that majority (41.3\%) of the respondents could sign only, followed by 26.0 percent who had no education, 22.7 percent had primary education (up to class 5) and 10.0 percent had complete SSC (Class X). Therefore, more than $3 / 5(67.3 \%)$ of the respondents did not acquire any formal education while the rest (32.7\%) had education of different levels. Khan et al. (2013) found that 73.0 percent of the fishermen were illiterate, 21.0 percent up to primary level and 6.0 percent had secondary level of education. Similarly, the present study found that 40.0 percent of the respondents had training, while 60.0 percent had no training exposure. However, training is essential to increase knowledge of the fishermen about fishing and its rules and regulations. It is also helpful to increase management skills of fisheries resources in the water bodies.

Half (50.0\%) of the respondents had contact with fisheries field assistant, 25.0 percent had contact with UFO (Upazila Fisheries Officer), but only 6.3 percent had contact with DFO (District Fisheries Officer). It was also 
observed that 18.7 percent of the respondents had no contact with the extension workers. Majority of this respondent $(60.0 \%)$ were not members of any social organization, but they have a very strong cooperation among them. The remaining 40.0 percent were members of various social organizations. Chakma (2015) in a study reported similar results.

Table 2. Distribution of the respondents according to socio-economic characteristics

\begin{tabular}{|c|c|c|}
\hline Variable & Frequency & Percent (\%) \\
\hline \multicolumn{3}{|l|}{ Age } \\
\hline Young (15-30 years) & 19 & 23.7 \\
\hline Middle (31-50 years) & 48 & 60.0 \\
\hline Old (above 50 years) & 13 & 16.3 \\
\hline \multicolumn{3}{|l|}{ Marital status } \\
\hline Married & 67 & 83.7 \\
\hline Unmarried & 13 & 16.3 \\
\hline \multicolumn{3}{|l|}{ Family type } \\
\hline Nuclear & 54 & 52.5 \\
\hline Joint & 36 & 47.5 \\
\hline \multicolumn{3}{|l|}{ Family size } \\
\hline Small (2-3) & 9 & 11.3 \\
\hline Medium (4-5) & 48 & 60.0 \\
\hline Large (6 and above) & 23 & 28.7 \\
\hline \multicolumn{3}{|l|}{ Education status } \\
\hline Illiterate & 21 & 26.0 \\
\hline Can sign only & 33 & 41.3 \\
\hline Primary level (up to class 5) & 18 & 22.7 \\
\hline SSC level & 8 & 10.0 \\
\hline \multicolumn{3}{|l|}{ Training exposure } \\
\hline Received training & 32 & 40.0 \\
\hline Did not receive training & 48 & 60.0 \\
\hline \multicolumn{3}{|l|}{ Extension contact } \\
\hline Department of Fisheries & 5 & 6.3 \\
\hline Upazila Fisheries Officer & 20 & 25.0 \\
\hline Fisheries Field Assistant & 40 & 50.0 \\
\hline No contact & 15 & 18.7 \\
\hline
\end{tabular}


Contd.

\begin{tabular}{lcc}
\hline Membership of social organization & 32 & \\
\hline Yes & 48 & 40.0 \\
No & & 60.0 \\
\hline Housing condition & 44 & 55.0 \\
\hline Kutcha & 26 & 32.5 \\
Semi-paka & 10 & 12.5 \\
Half-built & & \\
\hline Access to electricity & 75 & 93.7 \\
\hline Have connection & 5 & 6.3 \\
Not connected & & 25.0 \\
\hline Ownership of water body (pond) & 20 & 75.0 \\
\hline Yes (1-10 decimal) & 60 & 68.8 \\
No & & 12.5 \\
\hline Place of harvest disposal & 55 & 18.7 \\
\hline Local market & 10 & \\
Wholesale & 15 & 25.0 \\
Others & & 60.0 \\
\hline Fishing annual income & 20 & 15.0 \\
\hline Low income (less than BDT 70,000) & 48 & 100.0 \\
Medium income (BDT 71,000-100,000) & 12 & \\
High income (above BDT100,000) & 80 & \\
\hline Total & & \\
\hline & & \\
\hline
\end{tabular}

The housing condition of the respondents is divided into three categories: (1) Kutcha-house made of bamboo/tin with mud flooring or wall and flooring made of mud; (2) Semi paka-tin shed with tin wall and concrete flooring; and (3) Half-building made of tin shed with brick wall and concrete flooring (Table 2). The results show that more than half (55.0\%) of the respondents had kutcha house, about one-third (32.5\%) had semi-paka house, while only 12.5 percent had half-built house. Therefore, a large proportion (87.5\%) of the respondents had kutcha and semi-paka house categories, while only a small portion (12.5\%) had half-built house for shelter. Islam (2009) reported that 75.0 percent of fishermen's houses were kutcha, followed by 17.5 percent with tin shed and only 7.5 percent had half-built houses. The author opined that most of the dwellers around Kali river area of Bangladesh were poor and lived from hand-to-mouth.

Access to electricity facility is one of the major possessions for better living. It is difficult to pass a single moment without electrical energy in modern days. In the study area, it was found that almost all (93.7\%) of the respondents had access to electricity facility, but only 6.3 percent had no access to electricity. This might give the respondents the opportunity to enjoy modern facilities like TV, refrigerator, etc. Study of Das et al. 
(2015) revealed that only 23.0 percent of the fishermen had access to electricity and 77.0 percent had no access to electricity in Batiaghata, Khulna, Bangladesh. Water body is important to fishermen similar as land to the livestock and crop farmers. In the same vein, owned pond indicates better social status because of their own right to catch fish. Results in the study area show that 25.0 percent of the respondents own pond, while 75.0 percent had no pond and do not have ownership of any water body.

Right market place for selling of fish catch is important because it is a determinant of selling price. Results (Table 2 ) indicate that majority $(68.8 \%)$ of the respondents were able to sell their harvested fish in local market, 18.7 percent sold just after getting off from boat, while 12.5 percent sold at wholesale market. No fisherman had sold fishes in town as most of them lived far from town, thus it is very time consuming to come to the town for the purpose of disposing/selling fish catch only. Other reasons were poor communication facilities and limited knowledge on fish marketing channels. Chakma (2015) reported that 66.2 percent of the fishermen sold their harvested fish in local market, while only 33.8 percent of them sold fish in the nearby town.

The observed annual income of the respondents from fishing ranged BDT less than 70,000 to 100,000 above (= USD 844.887-1189.92 above). During the study period, it was observed that 25.0 percent of respondents had lowest annual income (less than BDT 70,000 from fishing), 60.0 percent had medium income (BDT $71,000-100,000$ ) and 15.0 percent had the highest annual income (above BDT 100, 000). Chakma (2015) observed similar results in her study on shifting cultivation in hill tracts by the Chakma women.

It is quite discernible that socioeconomic profile of the fishermen in the present study is not sustainable for livelihood. The condition cannot be separated from taking fishing as a tradition rather than means of securing quality life. This necessitates concerted efforts from appropriate authorities involving all stakeholders.

\section{Problems faced by the respondent fishermen}

Attempt has been made to find out the problems encountered by the fishermen in their daily lives, particularly those faced during fishing and selling of the harvest. Four major problems were identified and their rank in order of magnitude is given in Table 3.

Table 3. Distribution of the respondents according to problems they faced

\begin{tabular}{|c|c|c|c|}
\hline \multirow{2}{*}{ Category } & \multicolumn{2}{|c|}{ Respondent } & \multirow[b]{2}{*}{ Rank } \\
\hline & Number & Percent (\%) & \\
\hline Low annual catch & 54 & 67.5 & $1^{\text {st }}$ \\
\hline Lack of sufficient/appropriate fishing gear & 40 & 50.0 & $2^{\text {nd }}$ \\
\hline Overfishing & 34 & 42.5 & $3^{\text {rd }}$ \\
\hline Fishing area conflict & 21 & 26.5 & $4^{\text {th }}$ \\
\hline
\end{tabular}

The main problem was low annual catch (67.5\%), followed by lack of sufficient and appropriate fishing gear (50.0\%). As a result, fishermen cannot catch fish in large quantity according to their target. Due to overfishing (42.5\%), the quantity of fish catch and fish stock is decreasing day-by-day. Fishing area conflict (26.5\%) was another problem encountered by the respondents. 


\section{The conservation of fisheries biodiversity}

In a focus group discussion (FGD; $n=12$ ), two agenda were discussed with the participants including the major problems they faced and their probable solutions. They identified six major problems such as low annual catch, lack of sufficient and appropriate fishing gear, overfishing, fishing area conflict, degradation of fish habitats, and pollution of water bodies. During FGD, participants in consensus pointed out some management strategies to enhance fisheries biodiversity and fish catch in the study area. These include: i) prohibition of catching brood fish; ii) stop fishing juvenile fish; iii) restriction on nonselective and destructive fishing gears; iv) establishment of fish sanctuary in certain part(s) of the river; v) strict enforcement of fish acts/laws; and vi) arrange subsidies effectively during the fishing off-season.

\section{Conclusion and Recommendations}

Based on the major findings and relevant interpretation the following conclusions and recommendations are made

\section{Conclusions}

Majority of the fishermen were middle age, married, living in nuclear family of 4-5 members and partially literate (could sign only) with poor livelihood status.

- Fifty five fish species under 10 orders were recorded from the Titas River where the order Cypriniformes had high number of species and Beloniformes had only one species.

Major problems faced by the fishermen were low annual catch, insufficient fishing gear, overfishing and fishing area conflict.

\section{Recommendations}

A number of fish species were decreased and at the same time some were increased; necessary arrangements should be made to conserve them enforcing the rules and regulations, and controlling overfishing.

- It was found that more than half of the fishermen did not receive any training. Therefore, functional and need based training related to importance of fisheries diversity should be provided to them through extension agents with the collaboration of NGOs and other rural development agencies. Equally, alternate livelihood sources to supplement the present single source of income should also be provided by the appropriate authorities.

G Government may provide marketing facilities, fishing gears and designate fishing areas. This will go a long way in controlling area conflict among fishermen.

\section{References}

Ahmed MS (2008). Assessment of fishing practices on the exploitation of the Titas floodplain in Brahmanbaria, Bangladesh. Turkish Journal of Fisheries and Aquaculture Science, 8: 329-334.

Chakma L (2015). Fish biodiversity and livelihood status of fishermen living around the Kaptai lake. MS Thesis, Department of Agricultural Extension and Rural Development, Bangabandhu Sheikh Mujibur Rahman Agricultural University, Gazipur-1706, Bangladesh.

Coll M, Carreras M, Ciercoles C, Cornax MJ and Gorelli G (2014). Assessing fishing and marine biodiversity changes using fishers' perceptions: The Spanish Mediterranean and Gulf of Cadiz Case Study. PLoS ONE 9(1): e85670. doi:10.1371/journal.pone.0085670. 
Convention on Biological Diversity (2003). Report of the expert meeting on methods and guidelines for the rapid assessment of biological diversity of inland water ecosystems. UNEP/CBD/SBSTTA/8/INF/5.

Das MR, Sunuram R, Uttam K, Salma B and Satya TR (2015). Livelihood assessment of the fishermen community in the south west region of Bangladesh. Journal of Experimental Biological and Agricultural Science, 3(4): 353-361.

Department of Fisheries (2013). National fish week 2013 compendium. Department of Fisheries, Ministry of Fisheries and Livestock, Bangladesh.

Department of Fisheries (2015). National fish week 2014 compendium (in Bengali). Department of Fisheries, Ministry of Fisheries and Livestock, Bangladesh.

Food and Agriculture Organization (2015). The state of world fisheries and aquaculture. Rome, pp. 223.

Islam MA (2009). Socio-economic conditions of the fishing community living in the Kali river banks in Bhairab upazila of Kishorgonj district. MS Thesis, Department of Agricultural Extension Education, Bangladesh Agricultural University, Mymensingh, Bangladesh.

Khan MAR, Miah MI and Karim R (2013). Fish biodiversity and livelihood status of fishing community of Tista River, Bangladesh. Global Veterinaria, 10(4): 417-423.

Khanum R (2013). Socio-economic conditions of fishermen: evidence from Hakaluki haor of Bangladesh, Asian Business Review, 2(4): 19-21.

Kosturi MFA (2012). Studies on socioeconomic condition of fishermen of the Chalan beel under Tarash Thana of Sirajganj district in Bangladesh. Bangladesh Research Publication Journal, 6(4): 392-402.

Rahman MA, Abka A, Rahman MS and Sarma PK (2013). Poverty and food security analysis: A study of fishermen households in selected areas of Bangladesh. Journal of Bangladesh Agricultural University, 11(2): 293-299.

Rahman MM (2008). Study on socioeconomic status and fishing activities of fishermen of the Jamuna river under Islampur upazila of Jamalpur district. MS Thesis, Department of Agricultural Extension Education, Bangladesh Agricultural University, Mymensingh, Bangladesh.

Rahman MM, Hossain MY and Ahmed F (2012). Livelihood status and potential of alternative income generating activities in fisheries community of Nijhumdwip under Hatia upazila of Noakhali district in Bangladesh, Bangladesh. Research Publication Journal, 6(4): 370-379.

World Bank (2018). Bangladesh continues to reduce poverty but at slower pace. The World Bank. http://www.worldbank.org/en/news/feature/2017/10/24/bangladesh-continues-to-reduce-poverty-but-at-slower-pace.

Zaman T, Jewel MAS and Bhuiyan AS (2006). Present status of pond fishery resources and livelihood of the fish farmers of Mohanpur upazila in Rajshahi district. University Journal Zoology Rajshahi University, 25: 31-35.

(Manuscript received on February 19, 2018 and revised on August 29, 2018) 